\title{
36. ウイントウォッシャー液中の界面活性訪の土木構造物および環境に及ぼす影響 Effects of surfactant in windshield washer fluid on civil structure and environment
}

\author{
森吉昭博*·田畑昌祥*·太田幸雄*高野伸栄*·徳光克也** \\ Akihiro MORIYOSHI, Masaaki TABATA, Sachio Ohta、 \\ Shin-ei TAKANO, Katsuya TOKUMITSU
}

\begin{abstract}
This paper describes effects of surfactant in windshield washer fluid of automobiles on civil structure and environment. Surfactant in windshield washer fluid was spread by tire of automobiles and it easily dissolve asphalt in bituminous pavement under low content, whereas it caused to ion exchange between $\mathrm{Ca}+$ ions in cement concrete and $\mathrm{Na}+$ ions in windshield washer fluid for short time and reached to severe carbonization in cement concrete.

Surfactant was also found in air, accompanying with bitumen, diesel exhaust particulate (DEP) and tire. Then, it is considered that it also caused to local environmental change by black organic matters in air.
\end{abstract}

KEYWAORDS; surfactant, windshield washer fluid, civil structure, environmental pollution

\section{1. ば゙めに}

最近アスフアル舗装やセメントコンクリートで造った土木構造物の寿命が著しく低下し、かっ 大気污染も各種の対策をしているにもかかわらず一向に改善されていない。セメントコンクリートは従 来から言われていた炭酸ガスによる中性化であれば 20 年で $5 \mathrm{~mm}$ 程度の深さといわれているにもか かわらず、現在では 20 年で中性化梁さが $10 \mathrm{~cm}$ 超すものも現れている。一方、道路上に降った雨も 泡だらけでかつ、黒っぽい色をしているし、大気污染も、原因となる排出源毎の特定ができないため その対策に苦慮している。道路から流孔出た界面活性剂や本研究は種々の実験から、ウ仆彷ッシや一 液中のある種の界面活性剤がアスフアル卜舗装中の有機物であるアスフアルトを溶解するだけでなく、 セメントコンクリート中のカルシウム分と化学反忘(加水分解)し、新しい中性化現象をもたらすこと、また、 道路上に落ちたウ仆ウオッシか一液はアスフアルトを溶解したまま自動車タイヤにより空中に散布され、磨 耗したタイヤとともにこれが地域の気象にも変化をもたらす可能性のあることを明らかにした1)。

\section{2. ウイドウオッシャー液}

日本では昭和30年頃から経済の高度成長が始まり、これと共に大気中の油脂性の微粒子が多くなり、自動 車の前面のガラスの視野の確保が困難となり、日本で初めて導入されたのが陰イオン系の界面活性剂を主に含 むウインドウオッシャー液である。現在では主にポリオキシエチレン系のものが多用されている。これはこの材料が透明で あり、かつ少量で油分溶解の効果があるためである。現在世界中で同種の材料がウインドウオッシか一液として使わ

* 北海道大学大学院工学研究科 Hokkaido University, Graduate School of Engineering **日本道路侏技術研究所 NipponRoad Research Laboratory 
れている。雨の降り始めにアスファルト道路上に溜まった水が黒くかつ泡だらけとなるが、この水分中には この成分が存在することが確認されている。

\section{1 ウイドウオッシャー液の規格}

現在ウイドオッシャー液の規格はJSで定められているが、ここでは自動車を構成するガラス、ゴム、 塗料、プラスチックス等に対する損傷の程度がある限度以下となるよう決められており、一般には $0.5 \%$ 程度の濃度の界面活性剂が添加されている゙2。これは米国のウイドウオッシャ一液の規格ともほぼ同 一である゙。寒冷地ではこのウ价ウオッシか一液中に凍結防止用としてメチルアルコールが $30 \%$ 程度混入 されている。この他、防錆凨や安定剤が若干混入されている。一般にこの種の溶液成分のバクテリア による分解性は未だ不明である。

\section{2 ウイドウオッシャー液の性能}

自動車のウインドウオッシャー液で主に使用されているポリオキシエチレン系の界面活性剤は 40-50ppm のオーダーの濃度でも容易に油分を溶かすだけでなく、高温でも低温でも物性が安定しており、かつ 匂いや色もなく、蒸発もしにくい物質である ${ }^{4)}$ 。一般に口に入ると人体に対する毒性は強いとされてい る。また他の種類の界面活性剂と混合しても固化し、反応することは少ないとされている。

\section{3. アスファルトの溶解}

\section{1 アスファルトの性質}

アスファルトは黒い有機物であり、アスファルト舗装道路中には重量で約 5-9\%程度のアスファル トが骨材の接着剤として利用されている。現在のアスファルトは 100 年以上前のアスファルトのように 天然に産出したものではなく、道路の延長の増加とともに原油から次第に軽質分を取り出して製造し た人工のアスファルトである。アスファルトの特性は石油ショック以来原油のタイプや製造法が劇的に 変化したため、これ以前のアスファルトの特性とは全く異なっている。また原油の違いもあり、国により アスファルトの特性も著しく異なっている。しかし、セメントコンクリート舗装とアスファルト舗装の害績を 比較すると、世界中でアスファル卜舗装がほぼ $90 \%$ 以上の割合となり、低価格で維持や補修の容易さ、 平坦性の良さ等から圧倒的にアスファルト舗装の実績が多い。

今から約 10 年以上前までは寒冷地の冬季ですべての車両がスパイクタイヤを使用していたため、 このタイヤのピンによりアスファルト舗装中の骨材やアスファルトは 1 冬でひどい個所では $4-5 \mathrm{~cm}$ 程 度減っていた。このときは舞い上げられたアスファルトの粒子の大きさは $10 \mu$ 以上あり、人体の肺の 中まではいらなかったといわれている。しかし、実験室レベルではアスファルトを界面活性剂の $0.5 \%$ の濃度中に曝すとその粒子の直径は $1 \mu$ 程度となることが確認されている。

一方、アスファルト舗装の亀裂直下ではアスファルト層である上層路盤が逆Y字状になり、破壊さ れ、かつアスファルト分が全く存在しない状態となり砂利化している。この現象は亀裂のほとんどの個 所で生じており、これが舗装の平坦性や支持力不足やリフレクションクラックの発生に繋がっていると 考えられる。

\section{2 アスファルトの確認}

アスファルト中には多環芳香属の物質だけでなく、炭化水素類、飽和炭化水素類しいった様々な 成分が包含されている5)。米国ではアスファルトの煙だけでも人体に有害といわれ、この対策が舗装 の施工機械や混合物製造の工場で義務づけているが、界面活性剤のようなアスフアルトを溶解する素 材に対する規制は全く存在しない。米国では、日本でも現在進行中であるが、アスファルトのリサイク リングで野積みされたアスファルト混合物の残骸については蒸留水への溶出試験が行われ、アスファ 
ルト分が溶出しないから安全であると結論づけている ${ }^{6}$ 。なお、一般にディゼル排ガスからは5環以上 のベンゼン環を有する素材は存在しないといわれているが、日本の都市の大気中からは多環芳香属 の物質が多数検出されている7。

アスファルト舗装中のアスファルト分の確認は以下のように行なっている。

アスファルト舗装で亀裂が生じている個所を開削し、亀裂を挟しで $50 \mathrm{~cm}$ 程度の幅で深さ $1 \mathrm{~m}$ 以上に わたり、粒状路盤層(下層路盤、および路床)まで掘り下げると舗装の亀裂の真下から $1.2 \mathrm{~m}$ 深さま で黒、筋状の線が確認できる。舖装の砂利層の内部に水道管があり、この凍上対策として幅 $60 \mathrm{~cm}$ 程 度で厚さ3cmのスタ㐰ォームが埋設されていると、この上下が粒状路盤層で挟まれているのにもかか わらず、表面には真つ黒いアスファルトが数mmの厚さで全面に付着していた。アスファルトが単なる 粉塵として道路表面に堆積しているだけであればこのような現象は生じないと考えられる。また、主な 道路端上の土から最大 $1.5 \%$ のアスファルト分が確認されている。雨水枅や道路から水を誘導した溜 池では、水が黒くかつ池の底泥からはアスファルトが検出されている。

以上のアスファルトの確認は試料をメタノールで抽出したあと、再度加フォルム抽出を行い、これ を NMR(核磁気共鳴)にかけ、標準のアスファルトのスペクトルと比較して行った。

\section{4. セメントコンクリートの新しい中性化}

車両の大型化に伴い、橋の設計荷重の見直しが図られ、数年前に荷重が20トンから25トンに変 更された。これに伴い、日本全国に存在する約3000橋の床版の強度不足を補強するためスラブ増し 厚工法が採用され、2層で $8 \mathrm{~cm}$ のアスファルト層を剥がし、コンクリート床版の上に $4 \mathrm{~cm}$ 厚さのスチー ルファイバーコンクリートを施工し、その上にアスファルト舗装が $4 \mathrm{~cm}$ の厚さで施工されている。このと き、セメントコンクリート床版にかなりの砂利化現象やパンチングシア(押しぬきせん断)で生じたといわれ る穴が多数見出されている。この現象は日本だけでなく米国でも 13 年以上まえから確認されていた が、原因は全〈不明であった8)。

従来、セメントコンクリートの中性化は空気中の炭酸ガスにより生ずるといわれ、この研究が盛ん に行われている。しかし、最近アルカリ骨材反忘による亀裂とは異なり、その亀裂形状が樹枝状とはな らない、わゆる亀裂幅が細〈かつ亀裂間隔の狭いものが多数見受けられるようになった。のような


の炭酸ガスによる中性化深さより梁く、かつ進行速度が速いことが分かった。我々はこれをセメントコ ンクリートの新しい中性化と呼ぶこととする。

\section{1 新しいセメントコンクリートの中性化の特徴}

新しいセメントコンクリートの中性化による亀裂で表面に見えるものは5-10cm間隔の大きさの亀 裂で、亀裂幅はmm単位以下である。従って、地震のような外力がこの構造物に作用すると、表面の セメントコクリートの被りが全面的に剥離する。この剥離したセメントコンクリートの破断面の色が異常 に白いのが特徴である。

新しい中性化現象となる損傷の程度は従来のフェルルフタレン溶夜の塗布によるセメントコンクリート の中性化検査と同一方法で確認できる。

セメントコンクリートの橋では通常8cm のアスファルト舗装をしているにもかかからず、セメント ンクリート表面から内部に向かって中性化が進行している。この現象は空気に曝されたセメントコンクリ ートだけでなく、タイル張りの構造物の内部でもこの現象が生じている。

\section{2 セメントコンクリートの中性化の原因}

セメントコンクリートで新しい中性化が発生している個所の試料を採取して、メタノール抽出後、ク 
ロロフォルム抽出を行い NMR スペクトルで有機物の特定化を行うと、いずれの個所の試料からも黒 い有機物であるアスフアルトとエトキシ基を有する界面活性剤が共に検出された。この現象は空中お よび水中を問わない。アスファルト舗装やタイルで保護されている全てのセメントコンクリートが損傷を 起こしていることを全国規模で確認しているが、界面活性剤の種類は外国でもほぼ同一であるためこ とから世界中でも同一のセメントの中性化現象が生じていると考えられる。

室内でセメントコンクリートを作成し、エトキシ基を有する陰イオン系界面活性剂0.5\%水溶液中 に浸漬すると、水溶液が白く白濁し、かつセメントコンクリートの重量も短時間で減少する。この現象を 解明するため、ESCA を用いてカルシウム分と界面活性剤のナトリウム分の結合状態を調べると、セメント コンクリート中のカルシウム仏ノと界面活性剂中のナトリウム仏とが化学的に反応し置き換わっているこ とが判明した。このことはセメントコンクリート中のカルシウム分が時間と共に次第に減少すること、すなわ ち人間でいら骨粗獎症と全〈同一の現象がおきていることを意味している゙。

このような脱力ルラウム現象は新しいセメントコンクリートの中性化現象と結論される。しかし、最近あ まり見られないがタイル張りの風呂場でのタイルがときどき剥がれることは、石畧中のナトリウム分が先 と同様な反応をし、セメントコンクリート中のカルシウム分が溶け出したため、タイルが剥離したと考えられ るので、この現象は昔から存在していたと思われる。

\section{3 セxントコンクリートの破損現象}

セメントコンクリートが界面活性剂により中性化を起こすと、セメントコンクリートは膨張し、微細な 亀裂が発生する。界面活性剤を有する水溶液は表面張力が著しく低く、蒸留水の3倍の浸透力を持つ ためコンクリートの深部まで浸透するため、長時間にわたって、カルシウム分を溶解する。

長期間経過したセメントコンクリートの橋で $8 \mathrm{~cm}$ の厚さのアスファルト舗装で保護された床版につ いてダイヤモンドカッターで直径 $10 \mathrm{~cm}$ の試料を採取し、れを表面から $3 \mathrm{~cm}$ 厚さごとにさらに切断す る。この試料について界面活性剂の有無、圧裂強度、細粒分の表面積、有機物含有量、有機物の NMR スペクトル測定を実施したところ、床版の表面に近いほど強度が小さく、表面積は下部のものよ り1桁大きく、有機物含有量は多く、かつエトキシ基を有する界面活性剤がすべての試料から検出され、 それと同時にアスファルトも検出された。

セメントコンクリートは空中、水中にかかわ加ず、同様の損傷を示している。例えば、高闌、ピア、 縁石、建物の外部コンクリート等あらゆるコンクリートについて全国規模での損傷が確認されている。 特に高欄では被りのコンクリートが全面的に剥がれ落ち、内部の鉄筋が剥き出しとなった状態やコン クリート床版が砂利化した現象が確認されている。

一般にコンクリートの押抜きせん断で床版に穴があくとされているが、例えここに水が存在して もこのような砂利化現象は生じないし、この現象であれば走行軌跡上の全てで生ずることとなる。アス ファルト舗装にポットホールが生じ、絶えずこの補修を繰り返している個所ではコンクリート床版の砂 利化が生じている可能性が高い。アスファルト混合物の破壊時のひずみは一般に信じられているよう な大きさではなく、最小のひずみはコンクリートと全く同一であることから、アスファルト舗装に亀裂が 存在すると床版の傷みを調べたほうが良いと思われる ${ }^{10)}$ 。舗装と橋との研究の連携があればこのよう な現象はもう少し早く解明できたと考えられる。

中央分離帯のコンクリートは、長期間経過すると、みかけでは健全そうに見えるがはつり工事用 のピックによりコンクリートが片手で簡単に壊せるほど破壊強度が低下している。

建物の外壁のコンクリート(高さ $1.5 \mathrm{~m})$ で 20 年経過したものについて調査した結果、中性化深さ が $3 \mathrm{~cm}$ でかつ、この個所からセメントコンリリート $1 \mathrm{~m}^{3}$ あたり $15 \mathrm{~kg}$ 分相当の有機物(アスフアルト分) が検出 されている。 


\section{5. 大気污染}

現在でも大気污染がひどいといわれているものの、その排出源毎の特定がなされていないた め、大気中の有機物污染対策は一向に進展していない。筆者等は大気中の全有機物を八价りュームサン プラーで採取し(ここではこれを TPM と呼ぶ)、これを先と同様に分析すると中性化したコンクリート中 からとりだされた NMR スペクトルと全く同一のものが得られた(図一1 参照)。この結果、なんらかの 形で空気中に浮遊している有機物がコンクリート中に浸透したと考えられる。

夏タイヤ、ディゼル排煙(DEP)、アスファルトおよび上記TPMを用い、HPLCで4種類の物質 に仕分けして、そのうちのパラフ代成分についてのみ GC-MS 分析を実施し、TPM 成分を主関数とし た1次関数関係がこれらにあると仮定し、各成分の寄与率を相関係数の最大となる状態で求めると、 札幌の夏で北大工学部の6階建ての屋上ではそれぞれディーゼル排煙が55\%、アスファルトが36\%、 タイヤが9\%となった。

同一の手法で東北地方の高速道路の雨水枡中の泥について測定解析を行ったところ、その 寄与率はディーゼル排煙が $24 \%$ 、アスファルトが $56 \%$ 、タイヤが $20 \%$ であった。

これらはいずれも黒い有機物であることから、これらの粒子は太陽のエネルギーを吸収し、そ の高さの空気を暖めることともなるため、この地域の気象にも影響を与えると考えられる ${ }^{11}$ 。またこれら には粒子径の小さいものが多数含まれている可能性があるため人間の肺にも浸入していると考えら れ、人間の健康にも影響があると思われる。

\section{6. 水質污染}

アスファルトやタイヤは水と一緒に下水または川に流れる。下水では活性污泥法といらバクテリ ア処理で污水の浄化を全国規模で実施しているが、このウインドウオッシャ一液と同種の界面活性斉はバ クテリアでは処理不可能であるため、処理水は泡だらけとなり放流されている。従ってこの水の中には アスファルト、タイヤ等も処理されずに流れ出ている可能性があると考えられる。

\section{7. まとめ}

本研究はウインドウオッシャー液中のある種の界面活性剤がアスファルトやセメントコンクリート中の カルシウム分を簡単に溶出させること、またこの結果走行車両のタイヤによりアスファルトや界面活性剤お よびタイヤの粉塵が 空中に散布され、下水や川に流れること、またこの界面活性剂による土木構造 物の損傷も明らかにした。またアスファルト、タイヤ、ディゼル排煙等が空中浮遊の黒色有機成分に占 める排出源別割合も明らかにし、これら黒色有機成分は太陽の放射を吸収するため局地的な気象変 化を引起こす可能性のあることを示唆した。

\section{参考文献}

1) A.MORIYOSHI, S.TAKANO, M.ONO, M. OGASAWARA, M. TABATA, N.MIYAMOTO, and S.OHTA, Analysis of contribution to SPM by organic matters using high-performance liquid chromatography (HPLC), SAE technical paper series, 2002-01-0653 (2002)

2) Japanese Industrial Standard, (JIS K 2398, 1989)

3) Federal Specification, OC-1901, PG-406D

4）森田光徳、自然流せっけん読本、64-67、1996

5）金崎健児、岡田富男、アスファル、日刊工業新聞社、6、1963

6) Susan Parker, Asphalt: good citizen in landfills, Asphalt Contractor, 12,1991 
7）河合清之、石油製品と発がん、石油学会誌、第 18 巻、第2号、7-13、1975

8) Kandhal, P.S., Lubold, C. W. \& Roberts, F. L. Ed., The Journal of the Association of Asphalt Paving Technologists, Vol.58,40-70(1989)

9) A. MORIYSOSHI, M. TABATA, H. KITAGAWA, K. TOKUMITSU, and N. SAEKI, Decalcification of cement concrete structures and dissolution of bitumen by windshield washer fluid, Journal of the Japan Petroleum Institute, 45, (2), 84-88 (2002)

10）岡田清、今井宏典、道路橋のメンテナンス、阪神高速道路、243、1993

11）太田幸雄、大気エアロゾルの増加に伴う気候変化、エアロゾル研究、第6巻、第2号、98-105、1991

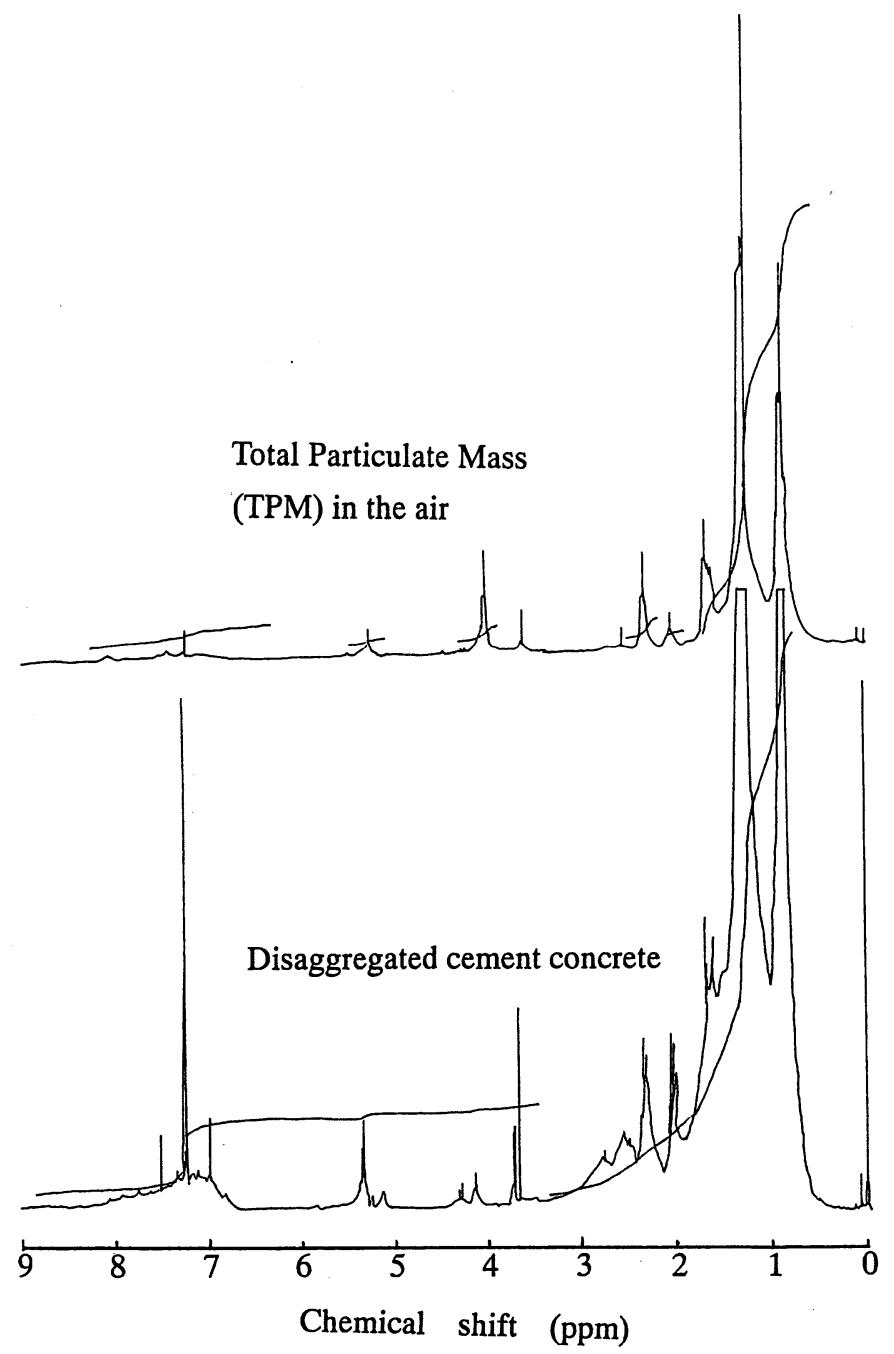

Figure 1 大気中の有機物(TPM)および砂利化したコン㚈ートの ${ }^{1} \mathrm{H}$ NMRスペクトル 